\title{
PERBANDINGAN SUMBER HUKUM ISLAM
}

\author{
Siska Lis Sulistiani \\ Prodi Hukum Keluarga Islam Fakultas Syariah Universitas Islam Bandung \\ siscaassidq@yahoo.co.id
}

\begin{abstract}
ABSTRAK
Sumber hukum Islam merupakan hal yang paling mendasar dalam proses penetapan sebuah hukum. Dalam Islam dikenal sumber hukum utama adalah Al-Quran dan sunnah, namun di sisi lain dari kalangan mu'tazilah memandang sumber utama hukum Islam bukanlah Al-Quran dan sunnah melainkan akal yang lebih utama. Perbedaan pandangan tersebut menjadi menarik untuk dibahas dalam bidang ushul fiqh perbandingan. Penulisan ini melakukan metode yuridis normatif, dengan jenis dan sumber data sekunder, dikumpulkan dengan metode dokumenter dan dianalisis dengan kualitatif deskriptif, sehingga bisa ditemukan perbedaan dan persamaan antaranya dua madzhab yang berbeda terkait sumber hukum Islam yang digunakan dalam menetapkan sebuah produk hukum.
\end{abstract}

Kata Kunci: Sumber, Hukum, Islam.

\begin{abstract}
The source of Islamic law is the most fundamental in the process of establishing a law. In Islam it is known that the main source of law is the Qur'an and the sunnah, but on the other side of the mu'tazilah view the main source of Islamic law is not the Qur'an and sunnah but the more important reason. The differences of view become interesting to be discussed in the field of ushul figh comparison. This writing performs normative juridical methods, with secondary types and sources, collected by documentary method and analyzed by qualitative descriptive, so that differences can be found and the similarities between two different schools of law related to the source of Islamic law used in establishing a legal product.
\end{abstract}

Keywords: Source, Law, Islam. 


\section{A. PENDAHULUAN}

Kata-kata "Sumber Hukum Islam" merupakan terjemahan dari lafazh Masâdir alAhkâm. Kata-kata tersebut tidak ditemukan dalam kitab-kitab hukum Islam yang ditulis oleh ulama-ulama fikih dan ushul fikih klasik. Untuk menjelaskan arti sumber hukum Islam, mereka menggunakan al-adillah al-Syariyyah. Penggunaan mashâdir al-Ahkâm oleh ulama pada masa sekarang ini, tentu yang dimaksudkan adalah se-arti dengan istilah al-Adillah al-Syar'iyyah. Dan yang dimaksud Masâdir al-Ahkâm adalah dalil-dalil hukum syara' yang diambil (diistimbathkan) daripadanya untuk menemukan hukum. Sumber hukum dalam Islam, ada yang disepakati (muttafaq) para ulama dan ada yang masih dipersilisihkan (mukhtalaf). Adapun sumber hukum Islam yang disepakati jumhur ulama adalah Al Qur'an, Hadits, Ijma' dan Qiyas. Para jumhur Ulama juga sepakat dengan urutan dalil-dalil tersebut di atas (Al Qur'an, Sunnah, Ijma' dan Qiyas), namun dari kalangan Mu'tazilah menempatkan akal dalam urutan pertama sebelum Al-Qur'an, sunnah, ijma dan qiyas. Maka penulis akan membahas dalam makalah ini mengenai pengertian, klasifikasi dan kehujahan sumber utama hukum Islam tersebut.

\section{B. PEMBAHASAN}

\section{Pengertian Hukum Islam}

Hukum Islam merupakan rangkaian dari kata "hukum" dan kata "Islam". Kedua itu secara terpisah, merupakan kata yang digunakan dalam bahasa Arab dan terdapat dalam Al-Qur'an, juga berlaku dalam bahasa Indonesia. “ hukum Islam” sebagai suatu rangkaian kata telah menjadi bahasa Indonesia yang hidup dan terpakai. Dalam bahasa Indonesia kata 'hukum' menurut Amir Syarifuddin adalah seperangkat peraturan tentang tingkah laku manusia yang diakui sekelompok masyarakat, disusun orang-orang yang diberi wewenang oleh masyarakat itu, berlaku dan mengikat untuk seluruh anggotanya ${ }^{1}$. Bila kata 'hukum' menurut definisi di atas dihubungkan kepada 'Islam' atau 'syara', maka 'hukum Islam' akan berarti: “ seperangkat peraturan berdasarkan wahyu Allah dan sunah Rasul tetang tingkah laku manusia mukalaf yang diakui dan diyakini mengikat untuk semua yang beragama Islam².

\footnotetext{
${ }^{1}$ Amir Syarifuddin.Ushul Fiqih Jilid 1. (Jakarta: Kencana, 2011), hlm. 6.

${ }^{2}$ Ibid.
} 
Sedangkan hukum dalam pengertian hukum syara' menurut istilah ulama ushul adalah khitob (doktrin) syar'i yang berhubungan dengan perbuatan mukallaf, baik berupa tuntutan, pilihan atau ketetapan.

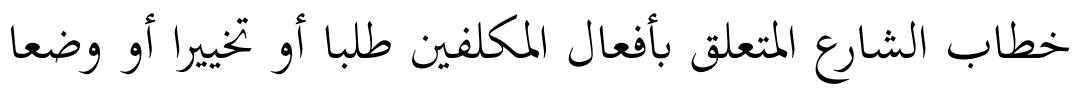

"Hukum adalah khitab Allah yang berkaitan dengan perbuatan mukalaf baik berupa perintah atau pilihan atau $w a d h{ }^{\prime 3}{ }^{3}$ ',

Para ahli ushul memberi istilah pada hukum yang berhubungan dengan perbuatan mukallaf dalam bentuk tuntutan atau pilihan dengan hukum taklifi, dan hukum yang berhubungan dengan perbuatan mukalaf dalam bentuk tuntutan atau pilihan dengan hukum taklifi, dan hukum yang berhubungan dengan perbuatan mukalaf dalam bentuk ketetapan dengan hukum wadh' $i$.

Adapun hukum syara' menurut istilah ahli fiqh adalah pengaruh yang ditimbulkan oleh doktrin syar'i dalam perbuatan (mukallaf), seperti kewajiban, keharaman dan kebolehan 5 .

\section{Pengertian Sumber Hukum Islam}

Menurut Kamus Umum Bahasa Indonesia sumber adalah asal sesuatu. Pada hakekatnya yang dimaksud dengan sumber hukum adalah tempat kita dapat menemukan atau menggali hukumnya. Sumber hukum Islam adalah asal (tempat pengambilan) hukum Islam. Sumber hukum Islam disebut juga dengan istilah dalil hukum Islam atau pokok hukum Islam atau dasar hukum Islam.

Kata 'sumber' dalam hukum fiqh adalah terjemah dari lafadz مصادر - مصدر, lafadz tersebut terdapat dalam sebagian literatur kontemporer sebagai ganti dari sebutan dalil ( الدليل atau lengkapnya “adillah syar'iyyah” ( الأدلة الثرعية) . Sedangkan dalam literatur klasik, biasanya yang digunakan adalah kata dalil atau adillah syar'iyyah, dan tidak pernah kata “ mashadir al-ahkam al-syar'iyyah” ( مصادر الأحكام الثرعية). Mereka

yang menggunakan kata mashadir sebagai ganti al-adillah beranggapan bahwa kedua kata tersebut memiliki arti yang sama ${ }^{6}$.

\footnotetext{
${ }^{3}$ Wad'i adalh sebab, syarat, atau mani'/penghalang suatu hukum

${ }^{4}$ Abdul Wahab Khalaf, Ilmu Ushul Fikih,(Jakarta: Pustaka Amani, 2003), hlm. 136.

${ }^{5}$ Ibid.

${ }^{6}$ Amir Syarifudin, Ushul... hlm.51.
} 
Bila dilihat secara etimologis, maka akan terlihat bahwa kedua kata itu tidaklah sinonim, setidaknya bila dihubungkan kepada 'syariah'. Kata sumber ( مصادر), atau dengan jamaknya sصادر, dapat diartikan suatu wadah yang dari wadah itu dapat ditemukan atau ditimba norma hukum. Sedangkan 'dalil hukum' berarti sesuatu yang memberi petunjuk dan menuntun kita dalam menemukan hukum Allah. Kata "sumber" dalam artian ini hanya dapat digunakan untuk Al-Qur'an dan sunah, karena memang keduanya merupakan wadah yang dapat ditimba hukum syara' tetapi tidak mungkin kata ini digunakan untuk 'ijma dan qiyas karena keduanya bukanlah wadah yang dapat ditimba norma hukum. ijma dan qiyas itu, keduanya adalah cara dalam menemukan hukum. Kata 'dalil'dapat digunakan untuk Al-Qur'an dan sunah, juga dapat digunakan untuk ijma dan qiyas, karena memang semuanya menuntun kepada penemuan hukum Allah $^{7}$. Berikut 2 pembahasan sumber utama hukum, yaitu:

\section{a. Al-Qur'an}

Kata Alquran dalam bahasa Arab berasal dari kata Qara'a artinya ' membaca. Bentuk mashdarnya artinya ' bacaan' dan 'apa yang tertulis padanya'. Seperti tertuang dalam ayat Al-Qur'an : - Secara istilah Alqur'an adalah Kalamullah yang diturunkan kepada Nabi Muhammad, tertulis dalam mushhaf berbahasa Arab, yang sampai kepada kita dengan jalan mutawatir, bila membacanya mengandung nilai ibadah, dimulai dengan surat Al-Fatihah dan diakhiri dengan surat An-Nas Al-Jurjani mendefinisikan Al-Qur'an: Al-Qur'an adalah (Kalamullah) yang diturunkan kepada Rasulullah tertulis dalam mushhaf, ditukil dari Rasulullah secara mutawatir dengan tidak diragukan. Adapun hukum-hukum yang terkandung dalam Alqur'an, meliputi

(a).Hukum-hukum I'tiqadiyyah, yaitu hukum yang berhubungan dengan keimanan kepada Allah swt, kepada Malaikat, kepada Kitab-kitab, para Rasul Allah dan kepada hari akhirat.

(b). Hukum-hukum Khuluqiyyah, yaitu hukum yang berhubungan dengan akhlak. manusia wajib berakhlak yang baik dan menjauhi prilaku yang buruk.

(c).Hukum-hukum Amaliyah, yaitu hukum yang berhubungan dengan perbuatan manusia. Hukum amaliyah ini ada dua; mengenai Ibadah dan mengenai muamalah dalam arti yang luas. Hukum dalam Alqur'an yang berkaitan dengan bidang ibadah dan bidang

\footnotetext{
${ }^{7}$ Ibid.
} 
al-Ahwal al-Syakhsyiyah / ihwal perorangan atau keluarga. disebut lebih terperinci dibanding dengan bidang-bidang hukum yang lainnya.

Hal ini menunjukan bahwa manusia memerlukan bimbingan lebih banyak dari Allah swt dalam hal beribadah dan pembinaan keluarga. Banyak manusia yang menyekutukan Allah, ini perlu diluruskan dan teguran, sedang keluarga merupakan unsur terkecil dalam masyarakat dan akan memberi warna terhadap yang lainnya. Adapun dalam bidang-bidang lain yang pengaturannya bersifat umum, memberi peluang kepada manusia untuk berpikir, tentu ini sangat bermanfaat, karena dengan pengaturan yang bersifat umum itu Alqur'an dapat digunakan dalam berbagai lapisan masyarakat, dan berbagai kasus dalam sepanjang jaman. Hukum Islam memberi peluang kepada masyarakat dan manusia untuk berubah, maju dan dinamis. Namun kemajuan dan kedinamisannya harus tetap dalam batas-batas perinsip umum Alqur'an. Perinsip umum itu adalah Tauhidullah, persaudaraan, persatuan dan keadilan.

\section{b. As-Sunah}

Sunnah secara bahasa berarti ' cara yang dibiasakan' atau ' cara yang terpuji. Sunnah lebih umum disebut hadits, yang mempunyai beberapa arti: $=$ dekat, $=$ baru, $=$ berita. Dari arti-arti di atas maka yang sesuai untuk pembahasan ini adalah hadits dalam arti khabar, seperti dalam firman Allah Secara Istilah menurut ulama ushul fiqh adalah semua yang bersumber dari Nabi saw, selain Al-Qur'an baik berupa perkataan, perbuatan atau persetujuan. Adapun Hubungan Al-Sunnah dengan Alqur'an dilihat dari sisi materi hukum yang terkandung di dalamnya sebagai berikut :

\section{a. Muaqqid}

Yaitu menguatkan hukum suatu peristiwa yang telah ditetapkan Al-Qur'an dikuatkan dan dipertegas lagi oleh Al-Sunnah, misalnya tentang Shalat, zakat terdapat dalam Al-Qur'an dan dikuatkan oleh Al-sunnah.

\section{b. Bayan}

Yaitu al-Sunnah menjelaskan terhadap ayat-ayat Al-Qur,an yang belum jelas, dalam hal ini ada tiga hal :

(1).Memberikan perincian terhadap ayat-ayat Al-Qur'an yang masih mujmal, misalnya perintah shalat dalam Al-Qur'an yang mujmal, diperjelas dengan Sunnah. Demikian juga tentang zakat, haji dan shaum. Dalam Shalat misalnya.

(2).Membatasi kemutlakan ( taqyid al-muthlaq) 
Misalnya: Al-Qur'an memerintahkan untuk berwasiat, dengan tidak dibatasi berapa jumlahnya. Kemudian Al-Sunnah membatasinya.

(3). Mentakhshishkan keumuman,

Misalnya: Al-Qur'an mengharamkan tentang bangkai, darah dan daging babi, kemudian al-Sunnah mengkhususkan dengan memberikan pengecualian kepada bangkai ikan laut, belalang, hati dan limpa.

(4) menciptakan hukum baru.

Rasulullah melarang untuk binatang buas dan yang bertaring kuat, dan burung yang berkuku kuat, dimana hal ini tidak disebutkan dalam Al-Qur'an.

\section{Sumber Hukum Islam dan Urutannya}

\section{a. Al-Qur'an, Sunah, Ijma dan Qiyas}

Berdasarkan penelitian menurut Abdul Wahab Khalaf telah ditetapkan bahwa dalil syara' yang menjadi dasar pengambilan hukum yang berhubungan dengan perbuatan manusia itu ada empat: al-Qur'an, as-sunah, ijma dan qiyas. Dan jumhur ulama telah sepakat bahwa empat hal ini dapat digunakan sebagai dalil, juga sepakat bahwa urutan penggunaan dalil-dalil tersebut adalah sebagai berikut: pertama al-Quran, kedua assunah, ketiga ijma, dan keempat qiyas. Yakni bila ditemukan suatu kejadian, pertama kali dicari hukumnya dalam al-Quran, dan bila hukumnya ditemukan maka harus dilaksanakan. Bila dalam al-Quran tidak ditemukan maka harus dicari ke dalam sunah. Bila dalam sunah juga tidak ditemukan maka harus dilihat, apakah para mujtahid telah sepakat tentang hukum dari kejadian tersebut, dan bila tidak ditemukan juga, maka harus berijtihad mengenai hukum atas kejadian itu dengan mengkiaskan kepada hukum yang memiliki nash ${ }^{8}$. Adapun dalil yang menunjukan urutan dalam menggunakan empat dalil di atas antara lain Qs. An-Nisa: 59

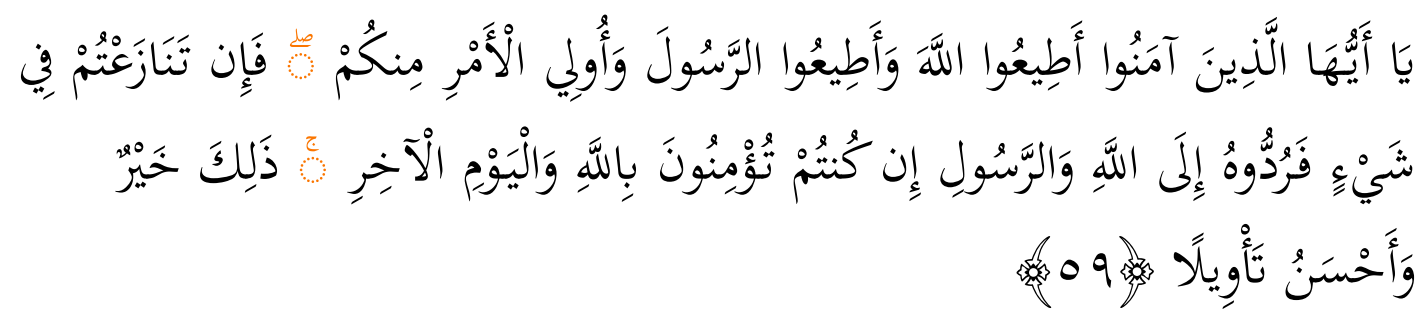

${ }^{88}$ Abdul Wahab Khalaf, Ilmu...., hlm.14. 
Hai orang-orang yang beriman, ta'atilah Allah dan ta'atilah Rasul (Nya), dan ulil amri di antara kamu. Kemudian jika kamu berlainan pendapat tentang sesuatu, maka kembalikanlah ia kepada Allah (Al Qur'an) dan Rasul (sunnahnya), jika kamu benarbenar beriman kepada Allah dan hari kemudian. Yang demikian itu lebih utama (bagimu) dan lebih baik akibatnya.(Qs.An-Nisa:59)

$$
\begin{aligned}
& \text { كيف تقضي إذا عرض لك قضاء ؟ قال: أقضي بكتاب الله قال: فإن لم بحد } \\
& \text { في كتاب الله ج قال: فبسنة رسول الله. فإن لم بحد في سنة رسول اللهجقال: أجتهد رأيي. } \\
& \text { ولاالو • (أي ولاأقصر في اجتهادي) قال: فضرب رسول الله على صدره و قال: الحمد } \\
& \text { لله الذي وفق رسول الله لمايرضى رسول الله. }
\end{aligned}
$$

Dari Mu'adz bin Jabal, bahwasanya Rasulullah saw. Ketika memerintahkannya ke Yaman bersabda, " bagaimana caramu memberi putusan hukum ketika menghadapi suatu masalah?" Mu'adz berkata, "saya akan memutuskan dengan kitab Alah (alquran)." Nabi bertanya, " jika kamu tidak menemukan hukumnya dalam kitab Allah?” jawab Mu'adz, “ maka dengan sunnah Rasulullah.” Nabi bertanya, “ jika kamu tidak menemukan hukumnya dalam sunnah Rasulullah saw?" Mu'adz menjawab , "saya akan berijtihad dengan pendapat saya, dan saya tidak akan memepersempit ijtihadku” rawi haditsberkata: maka Rasulullah saw menepuk dada Mu'adz dan bersabda, “ segala puji bagi Allah yang telah memberi pertolongan kepada utusan Rasulullah terhadap sesuatu yang diridhai oleh Rasulullah." (HR.Al-Baghawi)

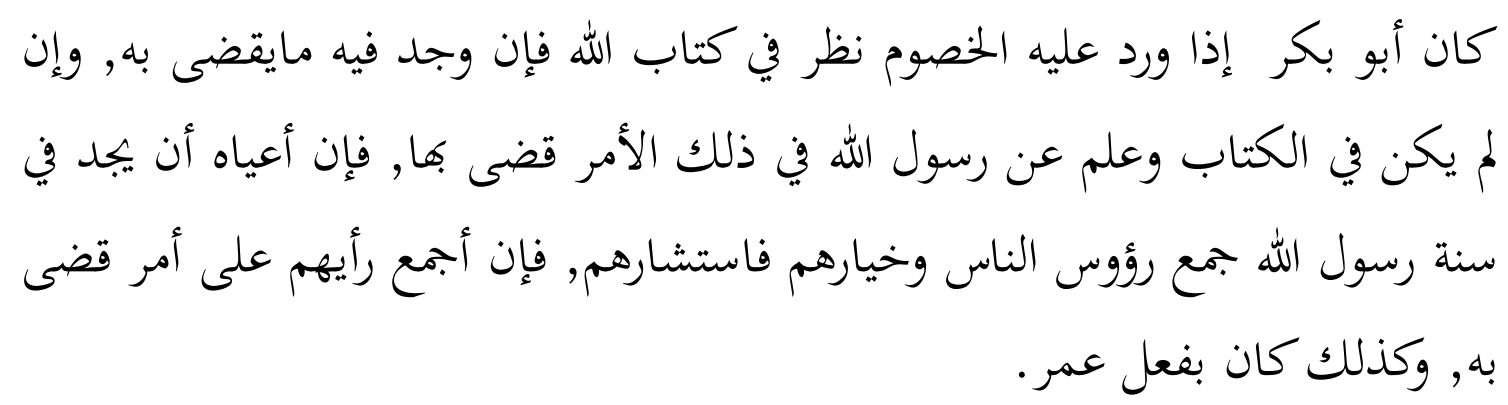

Dari Maimun bin Mahran, dia berkata, " Khalifah Abu Bakar ketika menerima pengaduan maka dia mencari hukumnya dalam kitab Allah, jika dia menemukan hukum untuk memutuskan perselisihan mereka maka segera dilaksanakan. Jika dalam al-quran tidakditemukan dan diamengetahui bahwa dalam sunnah Rasulullah adahukumnya, maka segera dilaksanakan. Jika dalam sunnah Rasululah tidak ditemukan, maka ia segera mengumpulkan para pemimpin dan tokoh umat Islam untuk bermusyawarah. Bila 
diperoleh kesepakatan pendapat di antara mereka maka segera dilaksanakn. Demikian juga yang dilakukanoleh Khalifah Umar.” (H.R Al-Baghawi)

Atas dasar bahwa hukum syara' itu adalah kehendak Allah tentang tingkah laku manusia mukalaf, maka dapat dikatakan bahwa pembuat hukum (law giver) adalah Allah Swt. Dengan demikian, ditetapkan bahwa Al-qur'an itu sumber utama bagi hukum Islam, sekaligus juga sebagai dalil utama fiqh. Al-Quran itu membimbing dan memberikan petunjuk untuk menemukan hukum-hukum yang terkandung dalam sebagian ayat-ayatnya. Para sahabat dan para jumhur ulama telah menetapkan dua hadits di atas sebagai dalil atas urutan penggunaan dalil. Namun ada dalil lain selain empat di atas yang mana mayoritas umat Islam tidak sepakat atas penggunaan dalil-dalil tersebut. Tetapi sebagian diantara mereka ada yang menggunakan dalil-dalil ini sebagai alasan penetapan hukum syara', dan sebagaian yang lain mengingkarinya. Dalil yang diperselisihkan pemakaiannnya itu ada enam: al-istihsan, maslahah mursalah, istishab, 'urf, madzhab shahabiy dan syara' manqoblana. Sehingga keseluruhan dalil syara' ada sepuluh, empat telah disepakati penggunaannya oleh mayoritas umat Islam, sedang enam masih diperselisihkan ${ }^{9}$.

Dalam konteks ini Imam Asy-Syatibi berkata: "Di dalam melakukan istinbath hukum, tidak seyogyanya hanya membatasi dengan memakai dalil al-Qur'an saja, tanpa memperhatikan penjabaran (syarah) dan penjelasan (bayan), yaitu Sunnah. Sebab dalam Al-Qur'an terdapat banyak hal-hal yang masih global (kulliy) seperti keterangan tentang shalat, zakat, haji, puasa dan lain sebagainya, sehingga tidak ada jalan lain kecuali harus menengok keterangan dari sunnah."10 Adapun ijma sebagai urutan sumber hukum selanjutnya, merupakan salah satu dalil syara yang memiliki tingkat kekuatan argumentatif setingkat di bawah dalil-dalil nash (Al-Qur'an dan Hadits). Ia merupakan dalil pertama setelah Al-Qur'an dan Hadits, yang dapat dijadikan pedoman dalam menggali hukum-hukum syara ${ }^{11}$.

Selanjutnya sebagai sumber hukum keempat adalah qiyas, jumhur ulama mempergunakan qiyas sebagai dasar hukum pada hal-hal yang tidak jelas nashnya baik dalam Al-Qur'an, hadits, pendapat sahabat maupun ijma ulama. Hal itu dilakukan dengan

\footnotetext{
${ }^{9}$ Abdul Wahab Khalaf. Ilmu.., hlm.16.

${ }^{10}$ Muhammad Abu Zahrah, Ushul Fiqih, (Jakarta: Pustaka Firdaus. 2010), hlm. 151.

${ }^{11}$ Ibid, hlm. 307.
} 
tidak berlebihan dan melampaui batas. Imam al-Muzani, salah seorang sahabat Imam Syafi'i menyimpulkan pandangannya tentang qiyas dalam ungkapannya: " para ahli hukum dari masa Rasulullah hingga sekarang selalu mempergunakan qiyas dalam setiap masalah hukum agama. Dan mereka sepakat bahwa, sesuatu yang setara dengan hak adalah hak, dan yang setara dengan bathil, bathil pula. Maka tidakdibenarkan seseorang mengingkari kebenaran qiyas, sebab ia merupakan upaya mempersamakan (menganalogikan) masalah dan membandingkannya. Sejalan dengan pendapat tersebut, Ibnul Qayim mengatakan,bahwa lintas pengambilan hukum itu seluruhnya bertitik tolak pada prinsip persamaan antara dua hal serupa dan prinsip perbedaan antara dua hal yang berbeda. Apabila dibalik prinsip tersebut tidak mempersamakan antara dua hal serupa, niscaya pengambilan hukum menjadi tertutup ${ }^{12}$.

\section{b. Akal, Al-Qur'an, Sunah Dan Ijma}

Berbeda dengan pandangan jumhur ulama, diantara ulama Mu'tazilah mendasari pandangannya dalam istinbath al-ahkam pada dalil akal sebagai urutan pertama,sebelum al-Quran, Sunah, dan ijma. Pandangannya yang demikian ini tidak lepas dari pandangan teologi Mu'tazilah yang dianutnya. Dalam teologi ini peranan akal begitu penting untuk menyelesaikan berbagai persoalan teologi dan memberikan corak tersendiri terhadap persoalan hukum dan metoda istinbat al-ahkam yang digunakannya. Dasar pertimbangan Mu'tazilah menempatkan dalil akal pada urutan pertama karena dengan akallah manusia mengetahui al-Qur'an, Sunah dan ijma. Selain itu, sebagai mana 'Abd al-Jabbar mendasar pandangan dalam istinbath al-ahkam pada dalil akal, sebagai urutan pertama, sebelum al-quran, as-sunah dan ijma. Melihat urutan pertama sebelum al-quran, sunah dan ijma. ${ }^{13}$ Melihat urutan seperti ini jelas bahwa peranan akal lebih tinggi dan penting dari dalildalil lainnya. Dasar pertimbangannya, karena dengan akal manusia mengetahui al-quran, sunah dan ijma, dengan akal manusia dapat membedakan antara yang baik dan yang buruk. Selain itu, Allah SWT juga tidak akan berbicara kecuali kepad manusia berakal. Semua pandangan di atas, menurutnya dapat dijadikan argument (hujjat) setelah manusia terlebih dahulu mengetahui Allah (ma'rifat Allah) dengan kekatan nalar akalnya ${ }^{14}$.

\footnotetext{
12 Ibid, hlm. 339-340.

${ }^{13}$ I.Nurol Aen. Disertasi Konsep Mushawwibat Al-Qadhi 'Abd Al-Jabbar dan Relevansi dengan Dasar Teologinya. (Jakarta: IAIN Syarif Hidayatullah. 1998), hlm. 116.

${ }^{14}$ Ibid, hlm. 117.
} 
Seperti halnya para filosof muslim, kaum Mu'tazilah juga mengartikan akal dengan "daya untuk memperoleh pengetahuan" dan juga "daya yang membuat seseorang dapat memperbedakan antara dirinya dan benda lain dan antara benda-benda satu dari yang lain”. Di samping itu akal mempunyai daya untuk mengabstrakkan benda-benda yang ditangkap pancaindera ${ }^{15}$. Selain itu, pandangan para filosof muslim dan umumnya kaum Mu'tazilah, tampaknya tidak sejalan dengan pandangan 'Abd al-Jabbar. Akal, dalam pandangan 'Abd al-Jabbar, bukanlah daya. Akan tetapi, akal melalui definisinya yang jami' mani' adalah himpunana pengetahuan tertentu, yang bila telah dimiliki oleh seseorang mukallaf, maka menjadi sahlalah pemikirannya, pengambilan dalilnya dan pelaksanaan kewajiban yang ditetapkan kepadanya ${ }^{16}$.

Dalam pandangan kaum Mu’tazilah, akal disamping mempunyai daya untuk memperoleh pengetahuan juga mempunyai daya untuk memperbedaan antara kebaikan dan kejahatan. Akal, dengan kata lain, mempunyai fungsi dan tugas moral. Sejalan dengan ini, menurut L Gardet dan M.M Anawati sebagaimana yang dikutip Harun Nasution, akal dalam pendapat Mu'tazilah adalah “ petunjuk jalan bagi manusia menjadi pencipta perbuatannya." ${ }^{17}$ Berdasarkan hal tersebut, akal bukanlah otak, tetapi akal adalah daya, sebagai yang digambarkan di dalam al-Quran, memperoleh pengetahuan dengan memperhatikan alam sekitarnya. Menurut Harun Nasution, akal dalam pengertian inilah yang dikontraskan dalam Islam dengan wahyu yang membawa pengetahuandari luar diri manusia, yaitu dari Tuhan ${ }^{18}$.

Berdasarkan uraian di atas, dapat dipahami bahwa sekalipun 'Abd al-Jabbar menempatkan dalil akal pada urutan pertama, namun tidak berarti bahwa ia menjadikannya sebagai hakim terhadap al-quran dan mendahulukan dalil-dalilnya dari pada dalil-dalil al-sam. Dalam menetapkan berbagai persoalan hukum, ia tetap berpegang kepada dalil-dalil al-sam $^{19}$.

\footnotetext{
${ }^{15}$ Harun Nasution, Akal dan Wahyu dalam Islam, (Jakarta: UI Press, 1986), hlm. 8-9.

${ }^{16}$ I. Nurol Aen. Disertasi ..., hlm. 93. Bunyi teks mengenai definisi akal adalah sebagai berikut: إعلم أن العقل هو عباره عن جملة من العلوم مخصوصة , متى حصلت في المكلف صبح منه النظر و الإستلال و القيام بأداء

Artinya: ketahuilah, bahwa sesungguhnya akal adalah himpunana pengetahuan tertentu yang bila telah dimiliki oleh seseorang mukalaf, maka menjadi sahlah pemikirannya, pengambilan dalilnya dan pelaksanaan kewajiban yang telah ditetapkan kepadanya.

${ }^{17}$ Ibid. hlm. 12.

${ }^{18}$ Ibid. hlm. 13.

${ }^{19}$ I Nurol Aen. Disertasi ...,hlm. 119.
} 
Pada pembicaraan tentang kewajiban 'aqliy, kita telah mengetahui bahwa pengetahuan dan pembuktian adanya tuhan merupakan kewajiban 'aqliy yang pertama dan paling penting diantara kewajiban-kewajiban lainnya. Sebab, kewajiban-kewajiban yang lain, seperti kewajiban mengetahui dalil-dali syara', baru dapat dilaksanakan sesudah seseorang mengetahui Tuhan. Jika manusia, dengan akalnya, mengetahui bahwa al-quran itu hujjat . demikian juga, jika manusia mengetahui bahwa tuhan mengutus rasul dengan benar, maka ia akan mengetahui sunah itu hujjat. Selanjutnya, jika diketahui bahwa rasul bersabda: “ umatku tidak akan sepakat di dalam kesalahan”. Maka diketahui bahwa ijma itu hujjat ${ }^{20}$.

Sebagai mana yang disebutkan, dalil itu ada yang 'aqliy dan sam'iy . bila sesuatu sudah bisa diketahui melalui dalil 'aqliy, kezhalim-an misalnya, maka tidak diperlukan dalil lain (sam'iy). Akan tetapi, bila tidak bisa diketahui dengan aqliy, maka dalil lain diperhitungkan . dalil sam'iy dibutuhkan dalam kaitannya dengan rincian kewajiban 'aqliy yang bersifat global. Sebaliknya, mengetahui dalil sam'iy hanya bisa dilakukan melalui khabar yang disampaikan rasul. Karena itu, diutusnya rasul merupakan suatu kemestian. Dengan demikian, kenabian dalam nisbatnya dengan akal, adalah hujjat penyempurna dalil dengan itu taklif menjadi baik. Diutusnya nabi, sekalipun merupakan pertolongan Allah, tetap mengharuskan adanya kegiatan berpikir pada diri mukallaf yang melalui itu kebebasan memilihnya diperlihara. Dalil-dalil al-sam'iy yang disampaikan rasul, antara lain, bisa berupa al-quran, sunah al-rasul, dan bisa pula berupa al-ijma. ${ }^{21}$

Adapun dalam urutan selanjutnya assunah, sebagai sumber ketiga dalam pandangan 'Abd al-jabbar, khabar yang dibawa oleh nabi dapat djadikan dalil, baik itu al-quran maupun sunnah, hadits, dan al-khabar adalah kata-kata yang mengandung arti yang sama, dalam pandangan kebanyakan ulama hadits dan 'Abd al-Jabbar. As-Sunah sebagai sumber pemikiran sesudah al-Quran, berisikan berbagai khabar yang diinformasikan oleh Nabi, baik berupa perkataan, perbuatan, maupun taqrir (pernyataan). Dalam pandangan Mu'tazilah, khabar yang diberikan oleh para perawi ada yang tidak diketahui kebenarannya dan kedustaannya. Khabar yang diketahui kebenarannya dapat diperoleh tanpa dalil, seperti al-khabar al-mutawatir tentang shalat lima waktu engan perantara dalil, seperti khabar tentang keesaan dan keadilan Tuhan. Al-khabar al-

\footnotetext{
${ }^{20}$ Ibid, hln. 120 .

${ }^{21}$ Ibid ,hlm.121.
} 
mutawatir tersebut dapat dijadikan landasan., baik untuk persoalan teologi maupun syari'ah. Adapun khabar yang tidak diketahui kebenarannya dan kedustaanya adalah khabar al-wahid. Menurut jumhur al-ulama, khabar ini dapat dijadikan dalil, baik untuk persoalan akidah maupun persoalan syari'ah. Berbeda dengan pendapat di atas, menurut kaum Muktazilah, khabar al-wahid dapat dijadikan dalil untuk persoalan syari'ah saja, sedangkan untuk persoalan akidah mereka menolaknya, kecuali bila khabar al-wahid tersebut sejalan dengan dalil akal. Karena persoalan akidah, menurut mereka, hanya dapat diperoleh kebenarannya dengan ilmu ${ }^{22}$.

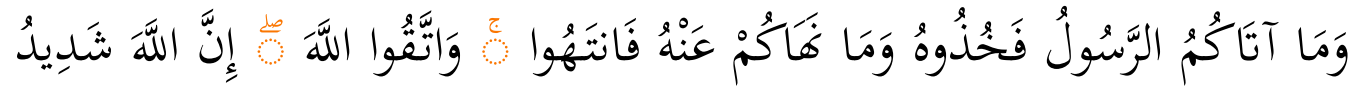

$$
\begin{aligned}
& \text { الْعَقَابِ }
\end{aligned}
$$

Apa yang diberikan Rasul kepadamu maka terimalah dia. Dan apa yang dilarangnya bagimu maka tinggalkanlah; dan bertakwalah kepada Allah. Sesungguhnya Allah sangat keras hukuman-Nya. (qs.al-hasyr:7)

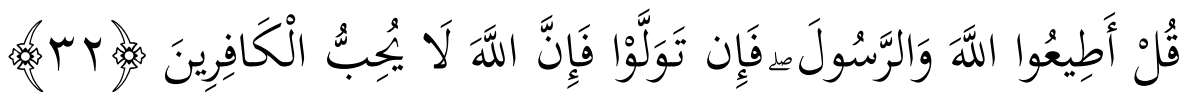

Katakanlah: "Ta'atilah Allah dan Rasul-Nya; jika kamu berpaling, maka sesungguhnya Allah tidak menyukai orang-orang kafir".(Qs.Al-Imran:32)

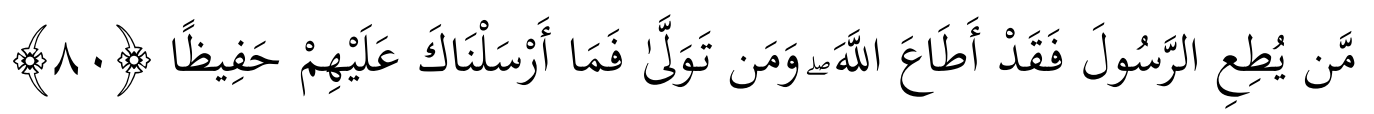

Barangsiapa yang menta'ati Rasul itu, sesungguhnya ia telah menta'ati Allah. Dan barangsiapa yang berpaling (dari keta'atan itu), maka Kami tidak mengutusmu untuk menjadi pemelihara bagi mereka . (Qs. An-Nisa:80)

Assunah sebagai sumber dalil ketiga, setelah dalil akal dan al-Quran, dengan ayat Qs.Al-Hasyr: 7, Qs. Al-Imran: 32, Qs.An-Nisa:80 dari ayat-ayat tersebut menunjukan bahwa hadits merupakan sumber ajaran Islam di samping dalil akal dan dalil al-Quran sebagai sumber utamanya. Hadits ini berfungsi sebagai penjelas bagi al-Quran . oleh

\footnotetext{
${ }^{22}$ Ibid, hlm.26.
} 
sebab itu hadits sebagai penjelas ini menempati urutan sumber ajaran Islam setelah alQur'an ${ }^{23}$.

Sumber pemikiran lain, sesudah as-Sunah, adalah ijma. Hal yang penting dalam ijma' ini adalah tercapainya kesepakatan orang banyak dalam satu masalah yang dianggap sebagai obyek kesepakatan mereka. Menurut ulama Mu'tazilah, mereka yang bersepakat harus memiliki pengetahuan tentang konsep ijma dan mengetahui kedudukannya yang sesungguhnya. Adapun yang dimaksud dengan 'orang banyak' dalam ijma, ini adalah para mujtahid yang beriman, yakni memahami dan mengakui kebenaran ajaran al-tawhid wa al-adl ${ }^{24}$. Pandangannya yang demikian ini tidak lepas dari pandangan teologi Mu'tazilah yang dianutnya. Sebagaimana diketahui, dalam teologi Mu'tazilah peranan akal amat tinggi dan penting dalam penyelesaian berabagai persoalan teologi. Hal itu relevan pula dengan sumber dalil lain yang digunakannya.

\section{Analisis dari Perbedaan Sumber Hukum Islam}

Ulama Syi'ah berpendapat bahwa akal merupakan sumber hukum fikih berkenaan dengan sesuatu yang tidak tersebut dalam al-Qur'an atau Sunnah, meskipun mereka mendefinisikan sunnah dengan arti yang lebih luas. Tetapi menurut syi'ah Imamiyah bahwa penerimaan akal sebagai salah satu sumber fikih Islam itu karena ada dasar syara'. Dengan adanya izin syara inilah kebenaran, menurut mereka dapat diperoleh melalui petunjuk akal. Sedang jumhur fuqaha tidak menjadikan akal sebagai pembuat hukum dan mereka mengembalikan sesuatu yang tak ada nashnya kepada sesuatu yang ada nashnya dengan beberapa jalan, baik dengan jalan qiyas, istihsan, atau dikembalikan kepada kemaslahatan yang dibenarkan syara' meskipun tidak ada dalil khusus yang menunjukannya.

Menurut Muhammad Abu Zahrah perbendaan pendapat antara ulama syi'ah dengan jumhur fuqaha tentang eksistensi akal (apakah bisa dianggap sebagai dalil atau tidak ketika tidak ada nash) adalah berpangkal dari adanya perbedaan dalam masalah tahsin aqliy (kebaikan menurut akal). Oleh karena itu dalam hal akidah golongan syi'ah imamiyah menganut madzhab Mu'tazilah, maka mereka memandang akal sebagai sumber hukum pada saat nash tidak ditemukan ${ }^{25}$.

\footnotetext{
${ }^{23}$ Ibid, hlm. 142.

${ }^{24}$ Ibid, hlm. 27.

${ }^{25}$ Muhammad Abu Zahrah, Ushul.., hlm.88.
} 
Selain itu, pendapat para jumhur ulama yang berpegang pada urutan sumber hukum adalah Al-quran, as-Sunah, Ijma dan qiyas pada hakikatnya tidak menafikan peranan akal sebagai alat untuk memahami sumber-sumber hukum Islam, hanya saja jumhur ulama tidak menjadikannya bagian dari sumber hukum Islam. Dan jelas hal ini akan menyulitkan bagi orang-orang yang memang kemampuan akalnya terbatas. Sedangkan pendapat ulama Mu'tazilah 'Abd al-Jabbar yang berpegang bahwa urutan sumber hukum Islam adalah akal, al-Qur'an, as-Sunnah dan Ijma. Dimana eksistensi akal begitu penting, namun tentunya hanya orang-orang yang telah memiliki pengetahuan dan kemampuan mengenai at-tauhid wa 'adl (mengetahui dan memahami kemaha adilan Tuhan) yang berhak menggunakan akalnya sebagai sumber hukum. Di sisi lain, Nabi Muhammad shallallahu 'alaihi wa sallam bersabda,

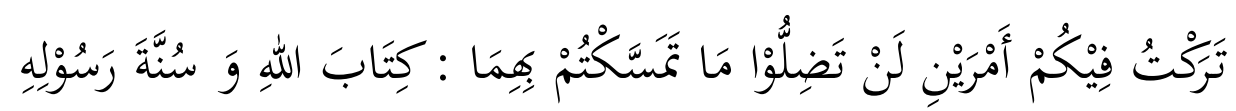

'Aku telah tinggalkan pada kamu dua perkara. Kamu tidak akan sesat selama berpegang kepada keduanya, (yaitu) Kitab Allah dan Sunnah Rasul-Nya’. (Hadits Shahih Lighairihi, H.R. Malik; al-Hakim, al-Baihaqi, Ibnu Nashr, Ibnu Hazm).

Namun, dalam Al-qur'an dengan jelas memerintahkan kita mengikuti apa yang diajarkan nabi yaitu berpegang pada Al-qur'an dan al-hadis sehingga dari ungkapan tersebut jelaslah kalangan Ahlu sunnah berpegang al-qur'an dan al-hadis sebagai sumber utama hukum Islam.

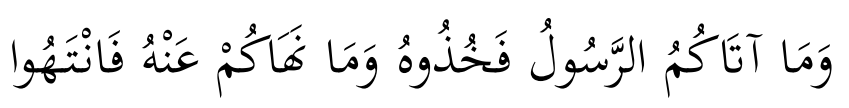

Artinya : “... dan apa-apa yang diberikan Rasul kepadamu maka terimalah ia. Dan apaapa yang dilarangnya, maka tinggalkanlah.” (QS. Al-Hasyr:7)

\section{SIMPULAN}

Sumber hukum dalam Islam sangat penting, karena ia merupakan sumber utama dalam menentukan sebuah hukum yang melandasi kehidupan seorang muslim. Perbedaan cara pandang tentang akal menjadikan perbedaan pendapat dikalangan jumhur fuqaha 
TAHKIM, Jurnal Peradaban dan Hukum Islam. Vol.1 No.1 (Maret, 2018), Hal 102-116

dengan kelompok mu'tazilah sehingga jelas menjadikannya berbeda dalam memandang tentang sebuah permasalahan hukum karena berbeda dalam memandang sumber utama hukum Islam. Dari permasalahan tersebut, menjadikan umat Islam harus memperlajari Al-Qur'an dan sunnah sebagai sumber utama hukum Islam agar tidak hanya meyakini tentang sumber utama hukum Islam namun juga memahaminya dengan baik.

\section{DAFTAR PUSTAKA}

Al-Qur'an Al-Kariem

Aen, I. N. (1998). Disertasi Konsep Mushawwibat Al-Qadhi 'Abd Al-Jabbar dan Relevansi dengan Dasar Teologinya. Jakarta: IAIN Syarif Hidayatullah.

Chaniago, A. Y. (1995). Kamus Bahasa Indonesia. Bandung: Pustaka Setia.

Khalaf, A. W. (2003). Ilmu Ushul Fikih. Jakarta: Pustaka Amani.

Nasution, H. (1986). Akal dan Wahyu dalam Islam. Jakarta: UI Press.

Syarifuddin, A. (2011). Ushul Fiqih Jilid 1. Jakarta: Kencana.

Zahrah, M.A. (2010). Ushul Fiqih. Jakarta: Pustaka Firdaus. 